KONSTRUKTIVISME, Vol. 7, No. 2, Juli 2015

p-ISSN: 1979-9438, e-ISSN: 2445-2355

FKIP Universitas Islam Balitar, Blitar

Web: konstruktivisme.unisbablitar.ejournal.web.id

\title{
PENERAPAN MODEL PEMBELAJARAN KOOPERATIF UNTUK MENINGKATKAN PEMAHAMAN HUKUM BACAAN QOLQOLAH DAN HASIL BELAJAR SISWA KELAS V SD 027 BALIKPAPAN
}

\author{
Sufyansyah \\ SDN 027 Balikpapan
}

\begin{abstract}
This study focuses on the implementation of cooperative learning models to increase achievement on rules of qolqolah in reading the holly Alquran. The subject of this study is the fifth grade students of SDN 027 Balikpapan. This study uses classroom action research design with two cycles. The results of classroom participation indicate that an increase is achieved from $40 \%$ in the cycle I into $72 \%$ in the cycle II. The mastery learning also increases from $64 \%$ to $100 \%$ respectively in cycle I and cycle II. This study concludes that teaching reading rules of qolqolah in reading Alquran using cooperative learning increases students learning activities and reading comprehension.
\end{abstract}

Keywords: cooperative learning, qolqolah, reading alquran.

\begin{abstract}
Abstrak
Penelitian ini membahas implementasi model kooperatif untuk meningkatkan penguasaan aturan qolqolah dalam membaca Alquran. Subjek penelitian ialah siswa kelas V SDN 027 Balikpapan. Penelitian menggunakan rancangan Penelitian Tindak Kelas dalam dua siklus. Hasil penelitian menunjukkan partisipasi siswa meningkat dari $40 \%$ pada siklus I menjadi $72 \%$ pada siklus II. Ketuntasan belajar meningkat terturut-turut dari $64 \%$ pada Siklus I menjadi $100 \%$ pada siklus II. Penelitian menyimpulkan bahwa teknik qolqolah dalam membaca Alquran meningkatkan kemampuan membaca kitab Suci Alquran dan pemahamannya.
\end{abstract}

Kata-kunci: pembelajaran kooperatif, qolqolah, membaca Alquran.

Dalam menghadapi era globalisasi pemerintah selalu meningkatkan SDM, dimana umat manusia telah memasuki abad modern, abad kemajuan ilmu dan tehnologi canggih. Untuk mengimbangi yang bersifat keduniawian, maka sangat perlu bidang rohani dibekali dengan pemahaman kepada ajaran-ajaran Agama Islam yang terkandung di dalam kitab suci Al-Qur'an. Upaya yang dilakukan Pemerintah antara lain adalah meningkatkan pemahaman baca tulis Al-Qur'an dengan berbagai cara baik melalui buku-buku pendidikan baca tulis Al-Qur'an, seminar, serta Karya 
Sufyansyah. 2015. Penerapan Model Pembelajaran Kooperatif untuk

Tulis IImiah, Taman-taman pengajian Al-Qur'an, guna meningkatkan pemahaman baca tulis Al-Qur'an dengan metode yang telah disahkan oleh Badan Penelitian dan Pengembangan (LITBANG) seperti metode: SAS, AlBanjari, Al-Bagdadi, An-Nur, Iqra dan lain-lain.

Di tingkat sekolah pemerintah melalui peran guru Agama Islam telah memprogramkan tuntas baca tulis Al-Qur'an. Berkaitan dengan tujuan di atas, khusus di SD 027 Balikpapan Utara sebagian besar siswanya belum memahami tentang hukum bacaan Qolqolah Sughra maupun Qolqolah Kubra, dalam membaca surah-surah pendek masih terdapat kesalahan membaca hukum bacaan Qolqolah, yang mesti dibaca dengan hukum bacaan Qolqolah, dibacanya tidak memakai Qolqolah sehingga bacaan kurang baik terdengar di telinga bagi yang mendengarnya. Kasus yang selama ini peneliti alami, bahwa pemahaman hukum bacaan Qolqolah siswa kelas V di SD.027 Balikpapan Utara masih tergolong rendah. Oleh sebab itu sangat perlu untuk diajarkan kepada siswa mengenai bentuk atau ciri-ciri dan cara pengucapannya yang benar, agar siswa dalam membaca Al-Qur'an sudah tidak ada lagi mengalami kesulitan tentang hukum bacaan Qolqolah karena identitasnya sudah jelas dan sudah dikenalnya secara baik.

Menyadari dengan keberagaman siswa yang heterogen dan perlunya menumbuhkan kebersamaan dalam belajar dan menyelesaikan masalah maka peneliti memandang perlu diterapkannya penggunaan Model Pembelajaran Kooperatif yang sangat mengedepankan aktivitas siswa untuk mencari dan mengolah dari kelompok-kelompok kecil yang memiliki tingkat kemampuan yang berbeda dalam menyelesaikan tugas kelompoknya. Kemudian adanya kerjasama, tolong-menolong, bantumembantu sesama kelompok. Banyaknya tugas diskusi kecil antar sesama kelompok, terjadi banyak tanya jawab, menimbulkan rasa keberanian untuk melaporkan/presentasi, mempunyai kedisiplinan dan rasa tanggung jawab, loyalitas antar sesama kelompok serta menjaga nama baik kelompok masing-masing. Penggunaan pendekatan ini sangat sesuai dengan pelaksanaan kurikulum 2006, yaitu Kurikulum Tingkat Satuan Pendidikan (KTSP), sehingga usaha Pemerintah untuk meningkatkan mutu pendidikan akan terlaksana dengan baik.

Hasil belajar yang diharapkan dengan pendekatan ini adalah (1) Siswa dapat memahami Hukum Bacaan Qolqolah dengan baik dan benar (2) Siswa dapat bersosialisasi dengan baik di kelas (3) Guru dapat menerapkan Model Pembelajaran Kooperatif dalam mata pelajaran yang diasuhnya. Diharapkan melalui pembelajaran yang dikemas dalam penelitian tindakan kelas ini dapat mempercepat pemahaman dalam membaca Al-Qur'an dengan baik dan benar.

Adapun pemahaman yang akan dicapai antara lain:

(1) Meningkatkan pemahaman hukum bacaan Qolqolah sehingga siswa lebih cepat memahami (Speed Understanding) dan lebih cepat mengingat (Speed Memorizing) (2) Agar terjadi perubahan sikap dan siswa mendapatkan hasil belajar yang sangat memuaskan, dan sangat diharapkan pada penerapan model tersebut. Dan hasil akhir yang diharapkan akan tumbuhnya rasa percaya diri terhadap siswa, tidak cepat dalam membantu kerja siswa, tidak mentertawakan hasil kerja siswa, 
mendorong agar tidak merasa takut, dan berani menanggung risiko, terbuka untuk mendengar pendapat siswa, membiasakan siswa untuk mendengarkan bila guru atau siswa yang lain berbicara, menghargai perbedaan pendapat, mendorong untuk memperbaiki kesalahan dan tidak kikir untuk memuji atau menghargai pendapat siswa.

Para ahli mengemukakan definisi belajar yang berbeda-beda. Namun, tampaknya ada semacam kesepakatan diantara mereka yang menyatakan bahwa perbuatan belajar mengandung perubahan dalam diri seseorang yang telah melakukan perbuatan belajar (Depag RI, 2002:25).

Sebagaimana ditekankan oleh John Dewey, menyangkut apa yang harus dikerjakan oleh pelajar untuk dirinya sendiri. Oleh sebab itu, inisiatif untuk belajar harus datang dari pelajar sendiri. Guru hendaknya memposisikan diri sebagai pembimbing dan pengarah yang mengemudikan perahu, sedangkan tenaga untuk menggerakan perahu tersebut berasal dari pelajar. Guru harus mendorong pelajar untuk belajar mandiri (Depag RI, 2002:28).

Menurut Jerome Bruner siswa belajar melalui keterlibatan aktif dengan konsep-konsep dan prinsip-prinsip dalam memecahkan masalah dan guru berfungsi sebagai motivator bagi siswa dalam mendapatkan pengalaman yang memungkinkan mereka menemukan dan memecahkan masalah (Depdiknas, 2004:9).

Parnell dalam Owens (2001) menyatakan bahwa dalam pengajaran kontekstual, tugas utama guru adalah memperluas persepsi peserta didik sehingga makna atau pengertian itu menjadi mudah ditangkap dan tujuan pembelajaran segera dapat dimengerti (Depdiknas, 2004:20).

Pembelajaran Kooperatif mempunyai tiga tujuan penting yaitu:

(1) Hasil belajar akademik pembebelajaran kooperatif bertujuan untuk meningkatkan kinerja siswa dalam tugas-tugas akademik. Banyak ahli berpendapat bahwa model kooperatif unggul dalam membantu siswa untuk memahami konsep-konsep yang sulit (2) Penerimaan terhadap keragaman Model kooperatif bertujuan agar siswa dapat menerima teman-temannya yang mempunyai berbagai macam perbedaan latar belakang. Perbedaan tersebut antara lain perbedaan suku, agama, kemampuan akademik, dan tingkat sosial (3) Pengembangan ketrampilan sosial.

Model kooperatif bertujuan untuk mengembangkan ketrampilan sosial siswa. Ketrampilan sosial yang dimaksud dalam pembelajaran kooperatif antara lain adalah: berbagi tugas, aktif bertanya, menghargai pendapat orang lain, memancing teman untuk bertanya, mau menjelaskan ide atau pendapat, bekerja dalam kelompok, dan sebagainya (Depdiknas, 2004:11). Menurut Bruner, jika seseorang mempelajari sesuatu pengetahuan itu perlu dipelajari dalam tahap-tahap tertentu agar pengetahuan itu dapat diinternalisasi dalam pikiran (struktur kognitif) orang tersebut.

(1) Tahap enaktif, yaitu suatu tahap pembelajaran sesuatu pengetahuan dimana pengetahuan itu dipelajari secara aktif, dengan menggunakan benda-benda kongkret atau menggunakan situasi yang nyata (2) Tahap ikonik, yaitu suatu tahap pembelajaran sesuatu pengetahuan dimana pengetahuan itu direpresentasikan (diwujudkan) dalam bentuk bayangan visual (visual imagery), gambar, atau diagram, yang menggambarkan 
kegiatan kongkret atau situasi kongkret yang terdapat pada tahap enaktif tersebut di atas (butir a) (3) Tahap simbolik, yaitu suatu tahap pembelajaran dimana pengetahuan direpresentasikan dalam bentuk simbol-simbol abstrak (abstract symbols), yaitu simbol-simbol arbiter yang dipakai berdasarkan keasepakatan orang-orang dalam bidang yang bersangkutan), baik simbol-simbol verbal (misalnya huruf-huruf, kata-kata, kalimat-kalimat),lambang-lambang matematika, maupun lambang-lambang abstrak lainnya (Depdiknas, 2004:8).

Merupakan strategi pembelajaran dengan menekankan pada kegiatan kelompok kecil dimana setiap siswa dengan kemampuan yang berbeda, kegiatan yang berbeda tetapi berkaitan dan bertanggung jawab atas dirinya, membantu teman dalam penguasaan materi. Sintaks untuk model pembelajaran kooperatif menyandarkan pada kerja kelompok kecil berbeda dengan pengajaran seluruh kelas dan memasukkan enam fase utama. Keenam fase pembelajaran kooperatif itu dirangkum pada tabel sebagai berikut:

Tabel 1. Sintak model pembelajaran kooperatif

\begin{tabular}{|c|c|}
\hline Fase & Tingkah laku Guru \\
\hline $\begin{array}{l}\text { Fase } 1 \\
\text { Menyampaikan tujuan dan } \\
\text { memotivasi siswa }\end{array}$ & $\begin{array}{l}\text { Guru menyampaikan semua tujuan } \\
\text { pelajaran yang ingin dicapai pada pelajaran } \\
\text { tersebut dan memotivasi siswa belajar }\end{array}$ \\
\hline $\begin{array}{l}\text { Fase } 2 \\
\text { Menyajikan informasi }\end{array}$ & $\begin{array}{l}\text { Guru menyajikan informasi kepada siswa } \\
\text { dengan jalan demonstrasi atau lewat bahan } \\
\text { bacaan }\end{array}$ \\
\hline $\begin{array}{l}\text { Fase } 3 \\
\text { Mengorganisasikansiswa ke } \\
\text { dalam kelompok-kelompok } \\
\text { belajar }\end{array}$ & $\begin{array}{l}\text { Guru menjelaskan kepada siswa } \\
\text { bagaimana caranya membentuk kelompok- } \\
\text { kelompok belajar dan membantu setiap } \\
\text { kelompok agar melakukan transisi secara } \\
\text { efisien }\end{array}$ \\
\hline $\begin{array}{l}\text { Fase } 4 \\
\text { Membimbing } \quad \text { kelompok } \\
\text { bekerja bekerja dan belajar }\end{array}$ & $\begin{array}{l}\text { Guru membimbing kelompok-kelompok } \\
\text { belajar pada saat mereka mengerjakan } \\
\text { tugas mereka. }\end{array}$ \\
\hline $\begin{array}{l}\text { Fase } 5 \\
\text { Evaluasi }\end{array}$ & $\begin{array}{l}\text { Guru mengevaluasi hasil belajar tentang } \\
\text { materi yang telah dipelajari atau tiap-tiap } \\
\text { kelompok mempresentasikan } \\
\text { kerjanya. }\end{array}$ \\
\hline $\begin{array}{l}\text { Fase } 6 \\
\text { Memberikal }\end{array}$ & $\begin{array}{l}\text { Guru mencari cara menghargai baik upaya } \\
\text { maupun hasil belajar individu maupun } \\
\text { kelompok }\end{array}$ \\
\hline
\end{tabular}

(Depdiknas, 2004:12)

\section{METODE}

Penelitian tindakan kelas ini dilakukan meliputi : Perencanaan atau persiapan, Pelaksanaan tindakan, Pengamatan/observasi, dan Refleksi. Pada proses perencanaan peneliti mengadakan berbagai persiapan untuk melaksanakan penelitian yaitu: 
1. Menentukan setting dan subjek penelitian,

2. Menentukan siklus penelitian

3. Menyusun instrumen penelitian

4. Menyusun jadwal pelaksanaan penelitian

5. Menentukan Komptensi Dasar yang akan dilaksanakan dalam penelitian,

6. Membuat rancangan pembelajaran dengan penerapan model kooperatif untuk pokok bahasan.

Setelah proses perencanaan kemudian dilaksanakan penelitian sesuai persiapan kemudian mengobservasi dan mengadakan refleksi sesuai siklus yang telah ditentukan. Penelitian tindakan kelas ini bersifat kualitatif dan data-data yang ada bersumber dari aktivitas siswa serta datadata dari hasil pengamatan dan wawancara, maka untuk menjaring data yang ada pada peneliti menggunakan metode sebagai berikut:

\section{Wawancara (Interview)}

Kegiatan wawancara ini dilakukan untuk menjaring data tentang minat dan sikap siswa sebelum dan setelah diperlakukan tindakan dalam penelitian, bersifat lentur dan terbuka serta dalam suasana yang tidak terlalu formal.

2. Pengamatan (Observation)

Teknik ini digunakan untuk menjaring data tentang aktivitas atau peristiwa yang dapat diamati selama kegiatan proses belajar mengajar berlangsung. Dalam hal ini peneliti ikut berperan aktif dalam kegiatan pembelajaran di kelas sehingga dapat mengamati serta memahami setiap permasalahan yang terjadi.

3. Tes

Metode ini digunakan untuk mencari data tentang hasil belajar siswa sebelum dan sesudah dilakukan penelitian, sehingga dapat diketahui sejauh mana peningkatan hasil belajar siswa setelah diberi tindakan.

Penelitian tindakan kelas ini dilaksanakan di SD Negeri 027 khusus untuk mata pelajaran Pendidikan Agama Islam. Sebagai subjek penelitiannya adalah siswa kelas $\mathrm{V}$ dengan jumlah 34 siswa yang terdiri dari 21 siswa laki-laki dan 13 siswa perempuan, dengan karekteristik siswanya kurang aktif dan rata-rata nilai ulangan harian sangat rendah.

SD Negeri 027 terletak di JI.II RT.021 Kelurahan Gunung Samarinda Kecamatan Balikpapan Utara, siswanya berasal dari berbagai latar belakang sosial ekonomi yang berbeda-beda. Peneliti adalah guru yang mengajar mata pelajaran Pendidikan Agama Islam dengan pengalaman mengajar selama 20 tahun.

Penelitian tindakan kelas ini direncanakan akan dilaksanakan dalam dua siklus berdasarkan tema atau pokok bahasan pada pencapaian komptensi dasar yaitu tentang Hukum Bacaan Qolqolah.

Penelitian tindakan kelas mengacu pada pendapat Kurt Lewin (1) Perencanaan (planning) (2) Tindakan (acting) (3) Pengamatan (observing) (4) Refleksi (reflecting).

Tahapan siklus penelitian ini dilakukan dalam dua siklus, untuk melaksanakan siklus pertama peneliti melakukan perenungan atau 
Sufyansyah. 2015. Penerapan Model Pembelajaran Kooperatif untuk

semacam pra penelitian terlebih dahulu untuk menentukan proses penelitian tindakan berdasarkan permasalahan yang ada. Kemudian siklus berikutnya dilaksanakan sama persis dengan siklus pertama dengan menambahkan hasil refleksi dari siklus pertama,

atau hasil perenungan dari siklus pertama dijadikan sebagai bahan pertimbangan perencanaan pada siklus berikutnya, demikian hingga didapatkan

Dalam penelitian ini sebagai alat pengumpul data utama adalah peneliti sendiri karena pada saat pengumpulan data peneliti berperan aktif dalam proses belajar mengajar di kelas sehingga hanya peneliti yang mampu memahami dan mengamati setiap kegiatan yang terjadi di kelas tersebut. Adapun instrumen-instrumen untuk menjaring data yang dilakukan dengan berbagai metode di atas adalah sebagai berikut:

1. Pedoman wawancara (Interview guide)

Berisi butir-butir soal yang bersifat terbuka yang dalam suasana tidak terlalu formal dilakukan di dalam kelas. Bentuk pedoman wawancara ini adalah berupa checklist untuk mengetahui sejauh mana minat dan tanggapan siswa tentang pembelajaran Hukum Bacaan Qolqolah dengan penerapan kooperatif sebagai data pendukung penelitian.

\section{Lembar Pengamatan (Observation Sheet)}

Berfungsi mengamati segala aktivitas yang dilakukan siswa selama proses pembelajaran berlangsung, dengan indikator sebagai berikut:

Sangat aktif, apabila rata-rata pengamatan sebesar 8,5-10

Aktif, apabila rata-rata hasil pengamatan sebesar 7,0-8,4

Cukup aktif, apabila rata-rata hasil pengamatan sebesar 5,5-6,9

Kurang , apabila rata-rata hasil pengamatan sebesar 4,0-5,4

Kurang aktif, apabila rata-rata hasil pengamatan sebesar 4,0

(Depdikbud, 1994/1995:10).

3. Tes

Bentuk tes yang akan digunakan adalah Tugas Individu dan Tugas Kelompok digunakan sebagai umpan balik bagi siswa dan peneliti (guru), agar mengetahui sejauhmana tingkat keberhasilan sebuah tindakan itu dilakukan.

Untuk menguji validitas data penelitian ini digunakan yaitu metode analisa data kuantitatif dan kalitatif. Metode analisa data kuantitatif lebih cocok untuk menganalisa data-data berupa angka. Sedang metode analisa data kualitatif lebih cocok untuk menganalisa data-data kwalitatif misalnya uraian tertulis dari dokumen, data uraian hasil wawancara, dan data dari hasil pengamatan.

Rangkaian akhir dari penelitian ini adalah mengadakan kesimpulan dari setiap permasalahan yang ditemukan selama proses pembelajaran. Pokok-pokok temuan hasil penelitian kemudian diverifikasikan lagi agar lebih mantap dan hasilnya dapat dipertanggung jawabkan maka peneliti mengadakan pengecekan ulang atau merefleksikan kembali seluruh proses tindakan yang telah dilakukan serta menguji validitas dengan sumber data yang lain baik dari sumber yang sama atau berbeda. Karena penelitian ini merupakan penelitian tindakan kelas yang sumber datanya bersifat deskriptif kualitatif. 
Penelitian tindakan kelas ini dilaksanakan di SD Negeri 027 Balikpapan Utara kelas $\mathrm{V}$. Peneliti memilih kelas $\mathrm{V}$ dengan pertimbangan bahwa siswa kelas ini sangat rendah dalam memahami hukum bacaan Qolqolah, sehingga hasil belajar siswa menjadi menurun pada siklus I.

Berdasarkan fakta tersebut maka peneliti mencoba mengadakan perubahan pendekatan dalam proses belajar mengajar di kelas $\mathrm{V}$, yaitu dengan cara menerapkan Model Pembelajaran Kooperatif Dalam Upaya Peningkatan Pemahaman Hukum Bacaan Qolqolah dengan mengacu pada pedoman penelitian tindakan kelas.

Penelitian ini dilakukan pada semester ganjil tahun pelajaran 2007/2008 yaitu tepatnya dimulai pada tanggal 15 September sampai dengan 08 Desember 2007 yang terbagi dalam dua siklus. Siklus I dilakukan pada tanggal 06 Nopember 2007 dengan materi Qolqolah dan siklus II dilaksanakan pada tanggal 13 Nopember 2007 dengan materi yang sama. Adapun skenario pembelajaran sebagai berikut di bawah ini:

1. Tahap 1

Pada tahapan ini guru mempersiapkan segala sesuatu yang akan digunakan sebagai media dan alat dalam pembelajaran.

2. Tahap II

Pada tahapan ini guru melaksanakan pembelajaran dengan menerapkan Model Pembelajaran Kooperatif dengan langkah-langkah sebagai beriktut.

Kegiatan Awal:

a. Menjelaskan tentang skenario pembelajaran dan sistem penilaian kelas

yang akan dilakukan guru dan siswa selama proses pembelajaran berlangsung.

b. Pre-tes untuk mengetahui kondisi awal siswa sebelum diberi tindakan.

c. Guru membagi siswa yang berjumlah 34 orang menjadi delapan kelompok

d. yang masing-masing beranggotakan 4 atau 5 orang secara heterogen

e. berdasarkan Kemampuan siswa (tinggi, sedang dan rendah), gender, suku.

f. Bila kelompok telah terbentuk maka siswa diminta untuk menentukan sendiri ketua sekaligus sebagai juru bicara,

g. Sekretaris dan anggota.

h. Guru menyajikan materi secara singkat dalam upaya mengantarkan siswa membangun pengetahuannya sendiri. 


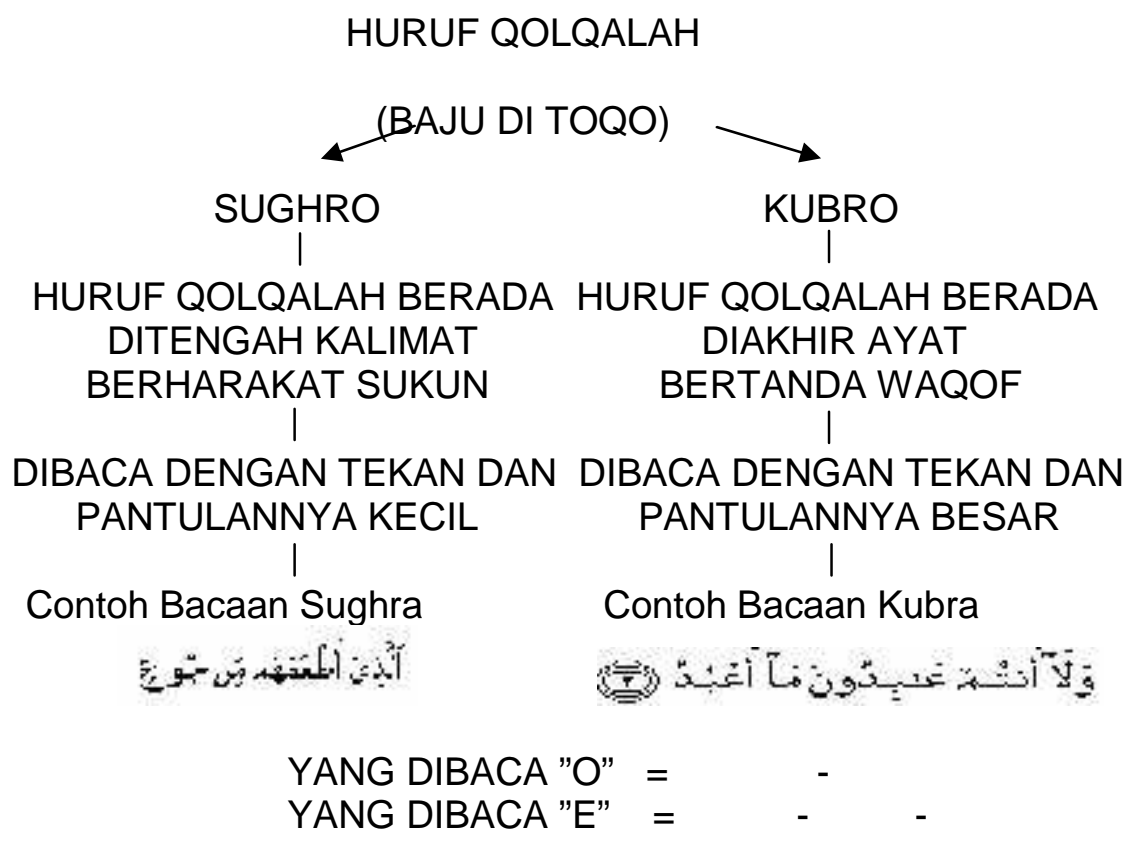

Kegiatan Inti:

a. Kelompok kerja

Guru memberikan worksheet/LKS kepada masing-masing kelompok dan

Setiap kelompok bekerja dalam kelompok kerjanya. Setiap anggota Kelompok berkewajiban membantu anggota yang lain untuk menguasai materi secara tuntas permasalahan worksheet/LKS tersebut. Guru perlu memberikan ketentuan kepada siswa mereka tidak boleh mengakhiri kegiatan belajar sebelum seluruh anggota kelompok menguasai materi 100\%.

b. Validitas dan Scoffolding

Setiap anggota kelompok mengecek jawaban mereka melalui kunci jawaban yang telah disediakan dalam LKS. Pada fase ini masingmasing kelompok mengajukan tanggapannya. Sedangkan fungsi guru hanyalah memberikan bantuan dan bimbingan agar validitas menghasilkan kesimpulan yang benar. Guru juga memberikan pujian kelompok yang bekerja dengan baik.

c. Pertanyaan Individu

Semua pertanyaan anggota kelompok kembali ketempat semula untuk menjawab pertanyaan individu. Siswa tidak diperkenankan lagi dengan anggota kelompok lainnya, mereka harus menunjukan bahwa mereka telah belajar sebagai individu.

d. Skor Individu dan Skor Kelompok

Siswa diminta saling menukar jawaban, atau mengumpulkan pekerjaan itu untuk diperiksa. Kemudian dibuat skor individu dan kelompok. 


\section{e. Penghargaan Kelompok}

Guru memberikan reward atau penghargaan untuk kelompok yang mencapai nilai yang baik. Penghargaan ini sangat penting mereka belajar kekompakan secara kelompok untuk membantu anggota yang lain dari kelompoknya, agar semua anggota kelompok menguasai materi dan keberhasilan akan mudah dicapai.

Kegiatan Akhir:

a. Pos tes untuk mengukur kondisi akhir siswa setelah diberi tindakan

b. Menutup dan menyimpulkan (refleksi)

\section{Pelaksanaan Tindakan}

Berikut ini kegiatan pelaksanaan tindakan kelas yang peneliti susun dalam bentuk skenario pembelajaran pada tabel berikut ini:

Tabel 2 Kegiatan Pelaksanaan Tindakan Kelas Siklus I

\begin{tabular}{cll}
\hline No & \multicolumn{1}{c}{ KEGIATAN GURU } & \multicolumn{1}{c}{ KEGIATAN SISWA } \\
\hline 1. & $\begin{array}{l}\text { Menjelaskan KD yang akan } \\
\text { dipelajari }\end{array}$ & Mendengarkan penjelasan \\
\hline 2. & Membagi kelompok & $\begin{array}{l}\text { Siswa berpencar mencari } \\
\text { kelompok }\end{array}$ \\
\hline 3. & Menghadirkan model & Mengamati dan mendengarkan \\
\hline 4. & Memantau kerja kelompok & $\begin{array}{l}\text { Kerja kelompok, dengan berdiskusi } \\
\text { dan menganalisa hukum bacaan } \\
\text { qolqolah }\end{array}$ \\
\hline 5. & $\begin{array}{l}\text { Guru berperan sebagai } \\
\text { fasilitator dan motivator }\end{array}$ & $\begin{array}{l}\text { Menunjukan hasil kerja kelompok } \\
\text { dengan diskusi kelas }\end{array}$ \\
\hline 6. & $\begin{array}{l}\text { Memberikan pembahasan } \\
\text { materi }\end{array}$ & Mendengarkan pembahasan \\
\hline 7. & Membagikan pos tes & Mengerjakan soal pos tes \\
\hline 8. & Memberikan tugas & Mencatat tugas \\
\hline
\end{tabular}

Tabel 3 Tugas Kelompok Siklus I

Perintah : Carilah di dalam Al-Qur'an/Zuz Amma/Buku lqra/Buku Pelajaran Pendidikan

Agama Islam Contoh Hukum Bacaan Qolqalah Kubra dan Shughra masingmasing 5 !

\begin{tabular}{|c|c|c|c|c|}
\hline \multirow{3}{*}{ NO } & \multicolumn{4}{|c|}{ QOQALAH } \\
\hline & & B R A & & GHRA \\
\hline & HURUF & CONTOHNYA & HURUF & CONTOHNYA \\
\hline
\end{tabular}


Hasil belajar hukum bacaan Qolqolah siklus I pemahaman, membaca dan menulis pada siklus I belum adanya peningkatan nilai baik pemahaman, membaca dan menulis. Pada siklus I ini nilai kelompok belum terjadi peningkatan karena siswa belum berani mengeluarkan pendapatnya, bersosialisasi, sehingga untuk memahami, membaca dan menulis hukum bacaan Qolqolah sangat lambat.

\section{Refleksi}

Setelah dianalis data siswa siklus I belum mencapai nilai standar ketentusan belajar, oleh sebab itu akan dilanjutkan pada siklus kedua

Tabel 4 Kegiatan Pelaksanaan Tindakan Kelas Siklus II

\begin{tabular}{cll} 
No & \multicolumn{1}{c}{ KEGIATAN GURU } & \multicolumn{1}{c}{ KEGIATAN SISWA } \\
\hline 1. & $\begin{array}{l}\text { Menjelaskan KD yang akan } \\
\text { dipelajari }\end{array}$ & Mendengarkan penjelasan \\
\hline 2. & Membagi kelompok & Siswa berpencar mencari kelompok \\
\hline 3. & Menghadirkan model & Mengamati dan mendengarkan \\
\hline 4. & Memantau kerja kelompok & \\
\hline 5. & $\begin{array}{l}\text { Guru berperan sebagai fasilitator } \\
\text { dan motivator }\end{array}$ & $\begin{array}{l}\text { Menunjukan hasil kerja kelompok } \\
\text { dengan diskusi kelas }\end{array}$ \\
\hline 6. & Memberikan pembahasan materi & Mendengarkan pembahasan \\
\hline 7. & Membagikan pos tes & Mengerjakan soal pos tes \\
\hline 8. & Memberikan tugas & Mencatat tugas \\
\hline
\end{tabular}

Tabel 5 LKS/Worksheet Siklus II

Perintah : Pilih Qolqalah Kubra atau Shughra dengan menggunakan Cheklist pada kata / kalimat di sebelah kanan !

\begin{tabular}{|c|c|c|}
\hline $\begin{array}{l}\text { Q O L Q A L A H } \\
\text { SUGHRA } \\
\end{array}$ & KATA / KALIMAT & NO \\
\hline & 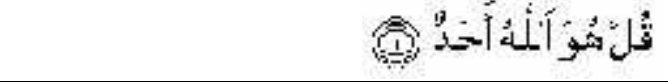 & 1 \\
\hline & 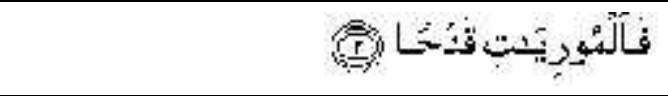 & 2 \\
\hline & 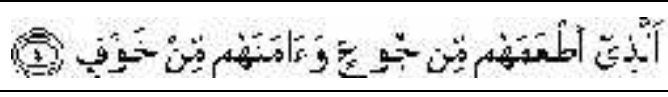 & 3 \\
\hline & 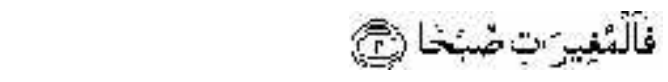 & 4 \\
\hline
\end{tabular}




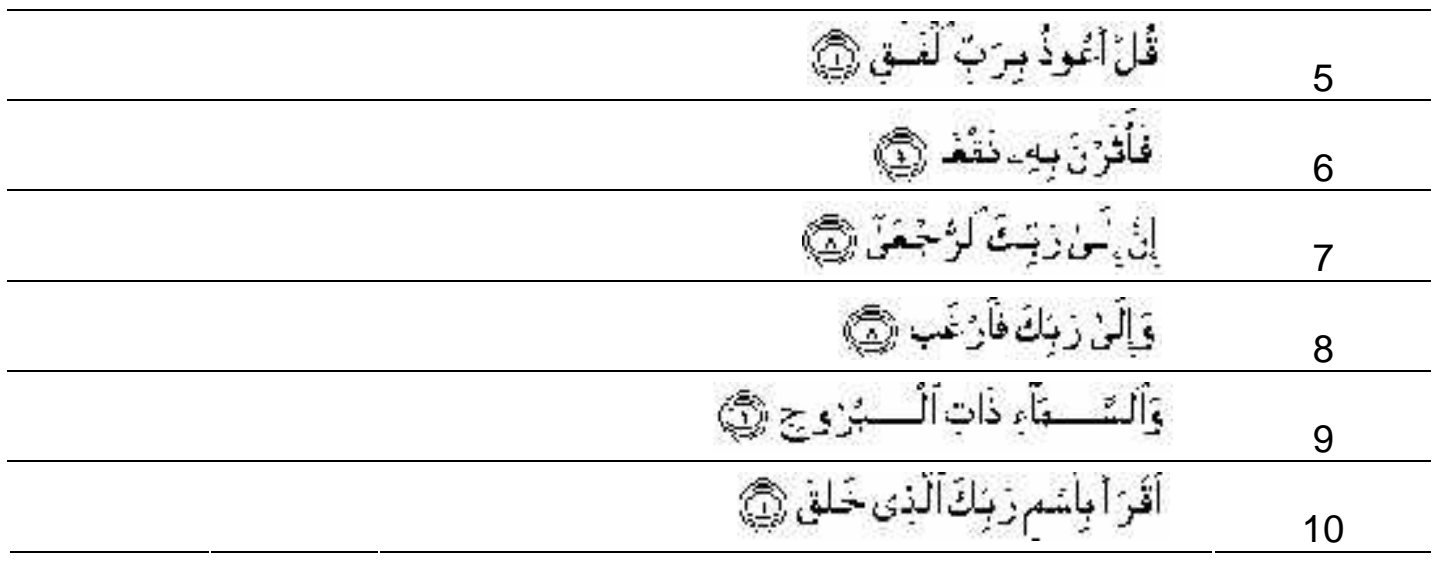

Hasil belajar hukum bacaan Qolqolah siklus II pemahaman, membaca dan menulis pada siklus II adanya peningkatan nilai pemahaman, membaca dan menulis. Pada siklus kedua ini nilai kelompok terjadi peningkatan karena siswa sudah berani mengeluarkan pendapatnya, bersosialisasi, sehingga untuk memahami, membaca dan menulis hukum bacaan Qolqolah dapat lebih cepat dengan menggunakan model pembelajaran kooperatif. Hasil belajar secara kelompok pada siklus I $(36 \%)$, sedangkan pada siklus II (100\%), berarti ada kenaikan sebesar $(64 \%)$

Tabel 6 Hasil evaluasi kelompok Siklus I dan II

MATA PELAJARAN

KOMPETENSI DASAR

MATERI POKOK

KELAS / SEMESTER
PENDIDIKAN AGAMA ISLAM

: Membaca QS Al-Lahab dan Al-Kafirun

: Surat Al-Lahab dan Al-Kafirun

: V $(\operatorname{lima}) / 1$ (satu)

\begin{tabular}{|c|c|c|c|c|c|}
\hline \multicolumn{2}{|c|}{ NOMOR } & \multirow{2}{*}{ N A M A } & \multirow{2}{*}{$L / P$} & \multicolumn{2}{|c|}{ SIKLUS } \\
\hline URT & INDUK & & & 1 & II \\
\hline 1 & 745 & Wisnu Ade Taufany & $\mathrm{L}$ & 100 & 100 \\
\hline 2 & 761 & Ria Wahyuni & $\mathrm{P}$ & 100 & 100 \\
\hline 3 & 763 & Santoso Utomo & $L$ & 90 & 100 \\
\hline 4 & 767 & Haswandi & $\mathrm{L}$ & 40 & 100 \\
\hline 5 & 794 & Ahmad Fitrianto & $L$ & 100 & 100 \\
\hline 6 & 795 & Wildan Safiqi & $\mathrm{L}$ & 100 & 100 \\
\hline 7 & 797 & Mira Alicia Nati & $\mathrm{P}$ & 100 & 100 \\
\hline 8 & 798 & Wiwik Prayogi & $\mathrm{P}$ & 80 & 100 \\
\hline 9 & 799 & Edi Kurniawan & $\mathrm{L}$ & 100 & 100 \\
\hline 10 & 800 & Adhe Masitoh Putri & $\mathrm{P}$ & 100 & 100 \\
\hline
\end{tabular}


Sufyansyah. 2015. Penerapan Model Pembelajaran Kooperatif untuk

\begin{tabular}{|c|c|c|c|c|c|}
\hline 11 & 801 & M. Yudha Fahreza & $\mathrm{L}$ & 90 & 100 \\
\hline 12 & 804 & Nanda Putri Kinanti & $P$ & 80 & 100 \\
\hline 13 & 806 & Avina Melyana .P & $P$ & 100 & 100 \\
\hline 14 & 807 & Abdul Halim & $\mathrm{L}$ & 100 & 100 \\
\hline 15 & 808 & Risky Sofian Gani & $\mathrm{L}$ & 80 & 100 \\
\hline 16 & 809 & Chandra Wijaya & $L$ & 100 & 100 \\
\hline 17 & 810 & M. Abdul Rizal & $\mathrm{L}$ & 100 & 100 \\
\hline 18 & 815 & Farjihan taufik & $\mathrm{L}$ & 40 & 100 \\
\hline 19 & 816 & Sandi Indah Lestari & $P$ & 80 & 100 \\
\hline 20 & 817 & Yolanda Trilia Putri & $P$ & 100 & 100 \\
\hline 21 & 818 & Hesti Cahyaningrum & $P$ & 80 & 100 \\
\hline 22 & 820 & Merita Dwi Wulan & $\mathrm{P}$ & 80 & 100 \\
\hline 23 & 821 & Debby Heru Prastya & $\mathrm{L}$ & 100 & 100 \\
\hline 24 & 823 & Yushi Aprindah Putri & $P$ & 100 & 100 \\
\hline 25 & 825 & Vera Farida & $\mathrm{P}$ & 80 & 100 \\
\hline 26 & 909 & M. Isrofan & $\mathrm{L}$ & 80 & 100 \\
\hline 27 & 953 & Annisa A. Dais & $P$ & 40 & 100 \\
\hline 28 & 954 & Johar Suwardi & $L$ & 90 & 100 \\
\hline 29 & 955 & M. Tri Hardiono & $\mathrm{L}$ & 80 & 100 \\
\hline 30 & 962 & Arif Mulyadi & $\mathrm{L}$ & 40 & 100 \\
\hline 31 & 967 & M. Hapiludin & $\mathrm{L}$ & 90 & 100 \\
\hline 32 & 968 & Fandi Razak & $\mathrm{L}$ & 100 & 100 \\
\hline 33 & 972 & M. Bayu Purwayadi & $\mathrm{L}$ & 100 & 100 \\
\hline \multirow[t]{2}{*}{34} & 973 & M. Bagus Purwayadi & $\mathrm{L}$ & 100 & 100 \\
\hline & & Jumlah & & 1240 & 3400 \\
\hline
\end{tabular}

$$
\begin{aligned}
& \text { SIKLUS I }=1240 \times 100 \%=36 \% \\
& \text { SIKLUS II }=3400 \times 100 \%=100 \% \\
& 340
\end{aligned}
$$

Tabel 7 Penentuan Kreteria Ketuntasan Minimal

Kelas : V (lima)

Stantas Komptensi : Membaca QS AI Lahab dan Al Kafirun (Qolqolah)

\begin{tabular}{cccccc}
\hline \multirow{2}{*}{$\begin{array}{c}\text { KOMP } \\
\text { DASAR / } \\
\text { INDIKATOR }\end{array}$} & ESENSIAL & $\begin{array}{c}\text { KOMPLEK } \\
\text { SITAS }\end{array}$ & $\begin{array}{c}\text { SARANA } \\
\text { PENDUKUNG }\end{array}$ & $\begin{array}{c}\text { INTAKE } \\
\text { SISWA }\end{array}$ & $\begin{array}{c}\text { PENENTUAN } \\
\text { KKM }\end{array}$ \\
\hline $\begin{array}{c}\text { Siklus I } \\
\text { Pemahaman }\end{array}$ & $\begin{array}{c}1 \\
\text { cukup }\end{array}$ & $\begin{array}{c}2 \\
\text { sedang }\end{array}$ & $\begin{array}{c}2 \\
\text { lengkap }\end{array}$ & $\begin{array}{c}2 \\
\text { sedang }\end{array}$ & $7 / 11 \times 100=63$ \\
\hline Menulis & $\begin{array}{c}1 \\
\text { cukup }\end{array}$ & $\begin{array}{c}2 \\
\text { sedang }\end{array}$ & $\begin{array}{c}2 \\
\text { lengkap }\end{array}$ & $\begin{array}{c}2 \\
\text { sedang }\end{array}$ & $7 / 11 \times 100=63$ \\
\hline Membaca & $\begin{array}{c}1 \\
\text { cukup }\end{array}$ & $\begin{array}{c}2 \\
\text { sedang }\end{array}$ & $\begin{array}{c}2 \\
\text { lengkap }\end{array}$ & $\begin{array}{c}2 \\
\text { sedang }\end{array}$ & $7 / 11 \times 100=63$ \\
\hline
\end{tabular}


FKIP Universitas Islam Balitar, Blitar Web: konstruktivisme.unisbablitar.ejournal.web.id

\begin{tabular}{cccccc}
\hline $\begin{array}{c}\text { Siklus II } \\
\text { Pemahaman }\end{array}$ & $\begin{array}{c}2 \\
\text { sangat }\end{array}$ & $\begin{array}{c}3 \\
\text { rendah }\end{array}$ & $\begin{array}{c}3 \\
\text { sangat } \\
\text { lengkap }\end{array}$ & $\begin{array}{c}3 \\
\text { tinggi }\end{array}$ & $11 / 11 \times 100=100$ \\
\hline Membaca & $\begin{array}{c}2 \\
\text { sangat }\end{array}$ & $\begin{array}{c}3 \\
\text { rendah }\end{array}$ & $\begin{array}{c}3 \\
\text { sangat } \\
\text { lengkap }\end{array}$ & $\begin{array}{c}3 \\
\text { tinggi }\end{array}$ & $11 / 11 \times 100=100$ \\
\hline Menulis & $\begin{array}{c}2 \\
\text { sangat }\end{array}$ & $\begin{array}{c}3 \\
\text { rendah }\end{array}$ & $\begin{array}{c}3 \\
\text { sangat } \\
\text { lengkap }\end{array}$ & $\begin{array}{c}3 \\
\text { tinggi }\end{array}$ & $11 / 11 \times 100=100$ \\
\hline
\end{tabular}

Nilai ketuntasan dalam bidang pendidikan agama Islam adalah 7,6 dan maksimal 10. Melihat dari hasil kelompok belajar siswa sangatlah tinggi yakni 100, maka standar KKM dapat tercapai.

\section{SIMPULAN DAN SARAN}

Dapat disimpulkan antara lain:

1. Penerapan Model Pembelajaran Kooperatif telah terbukti dapat meningkatkan pemahaman, membaca, menulis hukum bacaan Qolqolah.

2. Penerapan Model Pembelajaran Kooperatif dapat mengangkat nilai dari yang paling rendah. Kunci utama kerjasama, menjaga kekompakan, bersosiolisasi, kebersamaan, mempunyai tanggung jawab dan berdisiplin.

3. Penerapan Model Pembelajaran Kooperatif tidak monoton sehingga siswa tidak bosan, sehingga mengarah kepada PAIKEM (Pembelajaran, Aktif, Inovatif, Komunikatif, Effektif dan Menyenangkan)

4. Penerapan Model Pembelajaran Kooperatif dapat menggabungkan otak kanan dan otak kiri, sehingga intelgensi dan emosi siswa dapat terhubung dengan baik

Model Pembelajaran Kooperatif sangat perlu dipertahankan, karena sangatlah cocok bagi perkembangan siswa dalam memecahkan masalah, ada kerjasamanya, ada belajar kepemimpinannya sangat berguna untuk di masa yang akan datang.

\section{DAFTAR PUSTAKA}

Amir Tengku Ramly dan Erlin, 2006, Memompa Teknik Pengajaran Menjadi Guru Kaya, Tanggerang.

Depdikbud Dirjen Pendidikan Dasar dan Menengah, 1994/1995, Petunjuk Pelaksanaan Penilaian di Sekolah Dasar, Jakarta.

Depag RI Dirjen Pembinaan Kelembagaan Agama Islam, 2001, Metodologi Pendidikan Agama Islam, Jakarta

Depag RI Kelembagaan Agama Islam, 2003, Standar Penilaian di Kelas, Jakarta

Depdiknas Dirjen Pendidikan Dasar dan Menengah Direktorat Pendidikan Lanjutan Pertama, 2004, Materi Pelatihan Terintegrasi Matematika, Jakarta 
Sufyansyah. 2015. Penerapan Model Pembelajaran Kooperatif untuk Meningkatkan Pemahaman Hukum Bacaan Qolqolah dan Hasil Belajar Siswa Kelas V SD 027 Balikpapan. Konstruktivisme, 7(2): 142-154.

Depdiknas Dirjen Peningkatan Mutu dan Tenaga Kependidikan, 2007, Melaksanakan Penelitian Tindakan Kelas, Jakarta. 